\title{
再生サイクル用半径流タービンの始動特性に関する研究*
}

\author{
中野晋*1, 八木学*1, 岸 部忠 晴*1
} 坪内邦良*2, 柴田貴 範*3

\section{Starting Characteristic Analysis of a Radial Inflow Turbine for the Re-Generative Brayton Cycle}

\author{
Susumu NAKANO*4, Manabu YAGI, Tadaharu KISHIBE, \\ Kuniyoshi TSUBOUCHI and Takanori SHIBATA \\ ${ }^{* 4}$ Hitachi, Ltd. Energy and Environmental Systems Laboratory, \\ 832-2 Horiguchi, Hitachinaka-shi, Ibaraki, 312-0034 Japan
}

\begin{abstract}
Microturbines have been developed as compact gas turbines to be applied in the re-generative Brayton cycle. A typical microturbine is composed of a centrifugal compressor and a radial inflow turbine. As such, the microturbine has a characteristic peculiar to radial inflow turbines. An idling state known as the windage point for mass flow rate can be formed because of improper inlet flow conditions for turbine expansion flow. The present study looked at the relationships between the radius ratio of the radial inflow turbine to the centrifugal compressor and the starting characteristic, and at the effects of turbine inlet flow conditions on the starting characteristic. Fundamental equations for the relationships between the radius ratio and the starting characteristic were obtained. There was a limitation for the radius ratio of the turbine rotor to the compressor where stable operation without compressor surge could be obtained. Pressure loss and heat loss between the compressor outlet and turbine inlet where a recuperator is placed significantly affected the turbine starting characteristic. In particular, the heat loss had a considerable effect to increase starting pressure. Regarding stable operation near the limitation for the radius ratio of the turbine rotor to the compressor, operation with ignition at a low rotation speed was proposed and the effectiveness of the equations was compared with experiment results obtained with a $150 \mathrm{~kW}$ class prototype microturbine.
\end{abstract}

Key Words: Micro Gas Turbine, Gas Turbine, Compressor, Re-Generative Brayton Cycle, Surging, Starting Pressure, Radial Inflow Turbine

\section{1. 緒 言}

再生サイクルを適用した小型ガスタービンにマイ クロガスタービンがある. 1990 年代後半から，米国 を中心に実施された電力自由化による規制緩和によ り, 分散電源市場の拡大が予想され, 数種類の発電 設備が開発された (1)(2),(3). マイクロガスタービンは, 遠心圧縮機と半径流タービンの組み合わせによるも のが一般的な構造である(4). ガスエンジン等のレシ プロタイプの電源設備に比べ, 低騒音, 低振動, 低 NOx と環境面で優位性を持つこと，及び構造が簡 単であることからメンテナンスコストがレシプロタ

\footnotetext{
* 原稿受付 2009 年 4 月 23 日.

*1 正員, (株) 日立製作所エネルギー・環境システム研究所 (函312-0034 ひたちなか市堀口 832-2)。

*2 正員, フェロー, 元(株) 日立製作所電力・電機開発研究所.

*3 (株) 日立製作所エネルギー・・環境システム研究所.

E-mail : susumu.nakano.re@hitachi.com
}

イプに比べて低減できるなどの利点を有する(5).

一方で, 半径流タービンの場合, 翼車を通過する 流体に遠心力が作用するため, タービン出入口の流 入条件が整わないと，遠心力による昇圧作用で流体 がタービン入口から出口に膨張しない，いわゆる空 転状態という半径流形流体機械固有の問題を有する. 膨張流が発生してタービンとして始動する直前の空 転状態を流量ウィンディッジ点と呼び，過給機ター ビンを対象として，その特性に関して研究されてい る(の).しかし，過給機タービンは，圧縮機での昇圧 に加え, エンジン部での昇圧作用があるため, マイ クロガスタービンとは直接比較することはできない． マイクロガスタービンではタービン入口圧力は圧縮 機吐出圧に, また, タービン翼車の遠心力による昇 圧作用は，タービン翼車の大きさに依存することか ら，圧縮機とタービンの翼車外径寸法の比が，ター 
ビンの始動に影響を及ぼす。これまでの研究で，半 径流タービンと圧縮機の翼車外径寸法を具体的に公

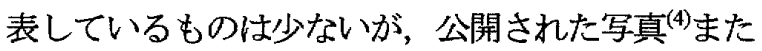
は図 ${ }^{(7)}$ から判断して, 外径比が 1.2 を超えるものは少 ない.しかし，マイクロガスタービン開発の初期段 階では，タービンと圧縮機の翼車外径比が $1.21^{(8)}$, $1.31^{(2)}$ と，1.2 を超えるものもあつたが, 両者とも夕 一ビンの自立運転を行ったという報告はされていな い.タービンの空転状態は圧縮機のサージを誘発し， 燃焼器の着火に影響を及ぼすため, 半径流タービン を適用したガスタービンシステムでは重要な問題で ある.しかし, 半径流タービンの始動特性に関して, 特に，タービンと圧縮機の翼車外径比との関係につ いては，これまでほとんど報告されていない。 本研究は，半径流タービンを適用した再生サイク ルガスタービンシステムにおけるタービン始動特性 として，タービンと圧縮機の翼車外径比がタービン 始動特性に及ぼす影響を明らかにすることを目的と する．始動特性に関する理論的な検討と，その検証 を, 本研究において開発を進めている $150 \mathrm{~kW}$ 級マイ クロガスタービンプロト機 ${ }^{(9)}$ の起動試験によって行 った.

\section{2. 記号}

$C_{p} \quad$ ：定圧比熱 $[\mathrm{J} /(\mathrm{kg} \cdot \mathrm{K})]$

$C_{\eta}$ : 効率比 $\mathrm{C}_{\eta}=\eta_{\mathrm{C}} / \eta_{\mathrm{T}}[-]$

$L \quad$ ：単位質量当たりの仕事またはエネルギ $[\mathrm{J} / \mathrm{kg}]$

\begin{tabular}{|c|c|}
\hline$N$ & : 回転数 $[\mathrm{rpm}]$ \\
\hline$P$ & : 圧力 $[\mathrm{Pa}]$ \\
\hline$\Delta P$ & : 圧力損失 $[\mathrm{Pa}]$ \\
\hline$R$ & : 反動度 [-] \\
\hline$r$ & : 半径 $[\mathrm{m}]$ \\
\hline$T$ & : 温度 $[\mathrm{K}]$ \\
\hline$\Delta T$ & ：温度降下［K] \\
\hline$\alpha$ & ： タービンと圧縮機の翼車外径比 Eq. (4) [- \\
\hline$\gamma$ & ： 温度降下係数 Eq. $(7)[-]$ \\
\hline$\eta$ & ： 効率 $[-]$ \\
\hline$\theta$ & : 圧力損失と大気圧の比 $[-]$ \\
\hline$\kappa$ & ： 比熱此 $[-]$ \\
\hline$\pi$ & ： タービンノズル入口全圧と大気圧の比 $[-1$ \\
\hline$\sigma$ & 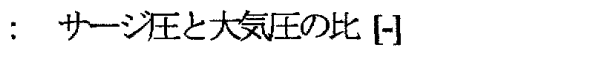 \\
\hline$\omega$ & ： 角速度 $[\mathrm{rad} / \mathrm{s}]$ \\
\hline$\eta$ & ：効率 $[-]$ \\
\hline
\end{tabular}

添字

$$
\begin{array}{ll}
a & : \text { 大気 } \\
C & : \text { 圧縮機 } \\
e x & : \text { 出口 } \\
\text { in } & : \text { 入口 } \\
N & : \text { ノズル } \\
T & : \text { タービン } \\
o & : \text { 全 } \\
1 & : \text { タービン出口から排出口の間 } \\
2 & : \text { 圧縮機出口とタービンノズル入口の間 }
\end{array}
$$

\section{3. タービンの始動圧力比}

3-1 タービンシステムの概要 図 1 に本研究で 対象とするマイクロガスタービン のシステム図を示 す、システムの主要構成要素は，遠心圧縮機，半径流 タービン, 永久磁石式高速発電機, 燃焼器, 再生熱交 換器, 及ひ双方向電力変換器加成る. 図 2 に本研究 で開発した マイクロガスタービンシステムの外観を 示す. タービンシステムの本体部分は, 発電機, 圧縮 機, タービン, 及び燃焼器で構成されている. 本体の 上流側に吸気ダクト,下流側に再生熱交換器が配置さ れ, パッケージの下段に双方向電力変換器が設置され ている.

大気から取り込まれた空気は 圧縮機で昇圧され再 生熱交換器に送られる. 再生熱交換器ではタービン排 ガスからの熱で圧縮機吐出空気を加熱する. 昇温され た空気は燃焼器に送られ，燃料と混合して燃焼する。 燃焼ガスはタービンで膨張して仕事を発生し，再生熱 交換器を通過して大気に排出される.

発電機ロータは永久磁石式発電機ロータで, 圧縮機 翼車とタービン翼車が 発電機ロータを共通軸として 一体化され，2 個の水潤滑軸受で支えられている(10). 本研究で対象とするタービン翼車の外観を図 3 に示 す.

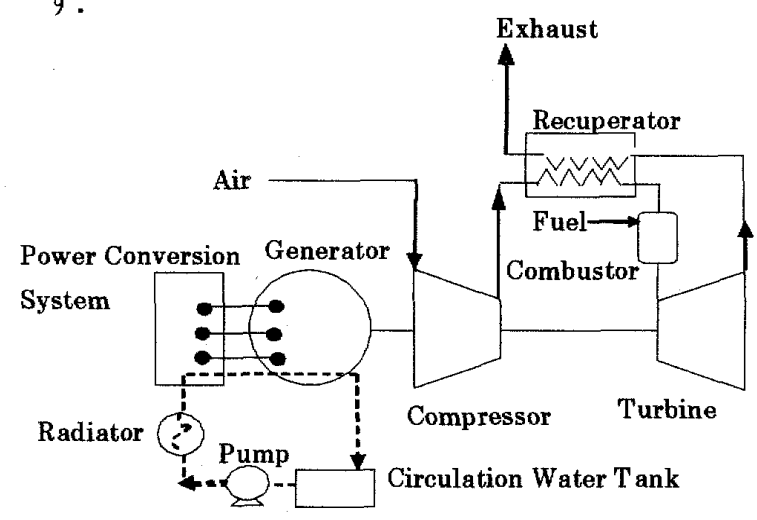

Fig. 1 Microturbine system diagram 


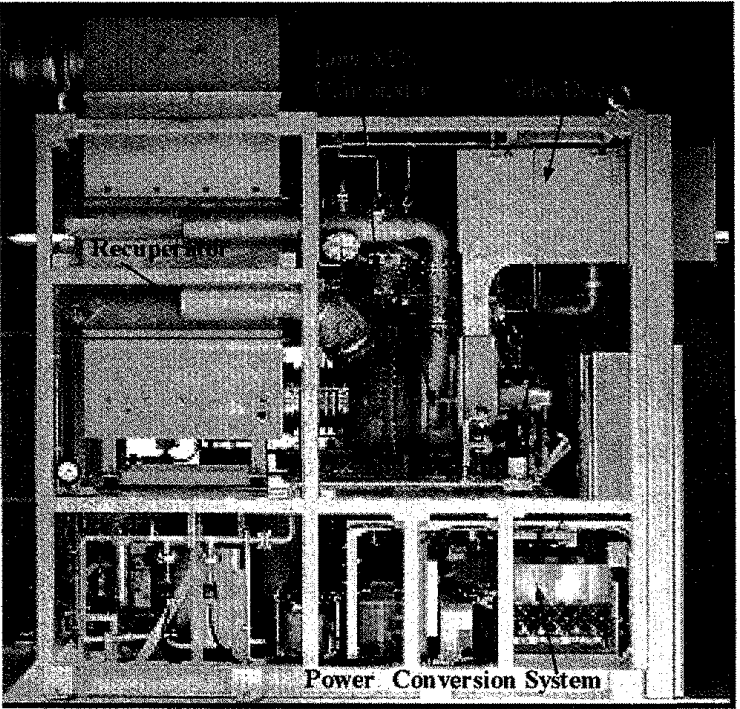

Fig. 2 Side view of the prototype microturbine

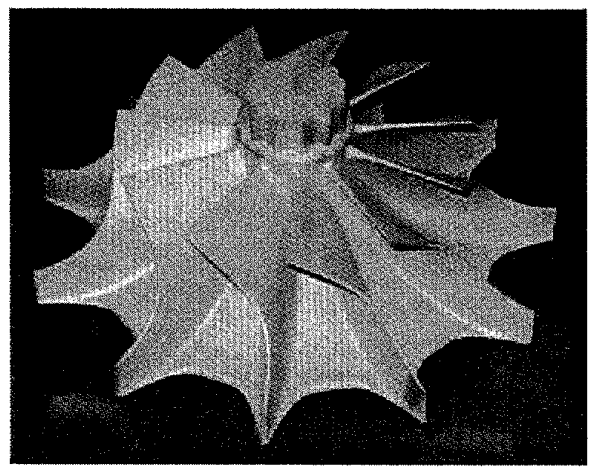

Fig.3 Photograph of turbine rotor

タービンの運転方法は以下のように行われる. 起動 時は発電機ステータに通電して 発電機を電動機とし て発電機ロータを起動する. 回転数が増加し着火でき る空気量に達したら 燃焼器に燃料を供給してパイロ ットバーナーで燃焼を開始する. 着火後は定格回転数 の 78\%回転数まで昇速して機器を暖機する. 燃焼器 八の供給空気温度が $600 \mathrm{~K}$ 以上に達したらメインバ 一ナーに燃料を投入し同時に回転数を定格回転数ま で昇速させる.メインバーナ一への燃料投入に伴い夕 一ビンの仕事率が圧縮機動力を 上まわるようになる とタービンシステムは発電を開始する. 起動時の系統 側から発電機側入の電力供給上, 発電時の発電機側か ら系統側への電力供給の切り替光は 双方向電力変換 器によって行われる.

\section{$3 \cdot 2$ タービンと圧綰機の翼車外径比と始動圧力比}

マイクロガスタービンの起動運転で, 燃焼器の着火 以前は, 圧縮機の断熱圧縮による昇圧昇温によるエン タルピーの増加がタービンの駆動源となる. 圧縮機の 吐出状態に対してタービンが始動できる限界まで夕
一ビン翼車外径を大きく取れれば，出力増加に対して 効果的である. 前述ように，既存のマイクロガスター ビンで, 半径流タービンの外径を圧縮機外径の 1.2 倍 以上にしてタービンシステムとして自立運転を行っ たものはほとんどなく,タービンと圧縮機の翼車外径 比の限界值は 1.2 近傍に存在するものと思われる.

なお，本マイクロガスタービンはタービン翼車の 上流側に，タービンノズルを設置しており，タービン 始動圧力を議論する際のタービン上流圧力は, タービ ンノズル上流全圧を用いる。

\section{4. 計算及乙解析方法}

4-1 タービン始動压力比 ここでは，タービ ン始動圧力に関する基礎式を導出する．単位質量当 たりのタービンの膨張仕事は断熱膨張を仮定すると 式 (1)で表される. また，遠心力によってタービン 出口がら口にに昇圧される際に流体に与えられるエ ネルギーは，単位質量当たりの流体に作用する遠心 力を翼車出口から入口に積分した形の式 (2)で表さ れる.

$$
\begin{aligned}
& L_{T}=\eta_{T} C_{p}\left(T_{0 i n, N}-T_{0 e x, T}\right) \\
& L_{C}=\eta_{C} \frac{\omega^{2}}{2}\left(r_{i n, T}^{2}-r_{e x, T}^{2}\right)
\end{aligned}
$$

式 (1)で示されるタービン仕事が式 (2)で示される圧縮仕 事よりも大きけれU翼車はタービンとして機能する. 逆 に式 (2)の值代式 (1)の值よりも大きけれは翼車はタービ ンとして機能しない，タービン始動点でのタービンノズ ル入口全圧とタービン出口全圧の比は式 (1)と式 (2)が等 しくなる点での圧力比である。つまり， $L_{T}=L_{C}$ として， タービンノズル入口全温とタービン出口全温の比をター ビンノズル入口全㽵とタービン出口全王の比で表し，整

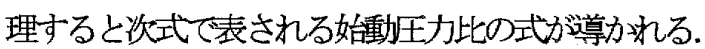

$$
\begin{aligned}
& \frac{P_{0 i n, N}}{P_{0 e x, T}}=\left[1-\frac{C_{\eta} \omega^{2}}{2 C_{P} T_{0 i n, N}}\left(\alpha r_{e x, C}\right)^{2}\left(1-\left(\frac{r_{e x, T}}{r_{i n, T}}\right)^{2}\right)^{\frac{\kappa}{1-\kappa}}\right. \\
& \text { ここで, } \\
& \alpha=\frac{r_{i n, T}}{r_{e x, C}}
\end{aligned}
$$




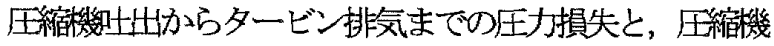
吐昉からタービンノズル入口までの放熱を無視すると， 田縮機出口全圧と入口全王の比とタービンノズル入口全 圧とタービン出口全圧の比江等しく, また, タービン) ズル入口全温は土縮機出口全温に等しくなる.式 (3)右辺 のタービンノズル人口全温を圧維機入口全温と，タービ ンノズル入口全圧とタービン出口全圧の比で表し整理す ると式 (3)侙 (5)に書き換えられる。

$$
\frac{P_{0 i n, N}}{P_{0 e x, T}}=\left[1+\frac{C_{\eta} \omega^{2}}{2 C_{P} T_{0 i n, C}}\left(\alpha r_{e x, C}\right)^{2}\left(1-\left(\frac{r_{e x, T}}{r_{i n, T}}\right)^{2}\right)\right]^{\frac{\kappa}{\kappa-1}}
$$

式 (5)はタービンの内外径比, タービンと圧縮轹の翼車外 径比，回転数，及ひ圧縮機入口空気温度加，そのター ビンを始動させるのに必要な圧力比を与える式である.

一方, 圧縮機叶出柿らタービン排気までの圧力損失と, 圧縮機地坊かタービンノズル入口までの放熱として, その間の温度降下を考慮すると, 式 (5)からタービンの始 動に必要なタービンノズル入口全圧と大気圧の比 $\pi$ は次 式のようになる.

$$
\begin{aligned}
& \pi=\frac{P_{0 i n, N}}{P_{a}} \\
& =\left[\left(1+\theta_{1}\right)^{\frac{\kappa-1}{\kappa}}+\frac{C_{\eta} \omega^{2}}{2 C_{P} \gamma T_{0 i n, C}}\left(\alpha r_{e x, C}\right)^{2}\left(1-\left(\frac{r_{e x, T}}{r_{i n, T}}\right)^{2}\right]^{\frac{\kappa}{\kappa-1}}\right.
\end{aligned}
$$

$\gamma$ は，タービンノズル入口全温を圧力損失及び温度降下 を考慮して圧縮入口全温で表すときの係数で, 式 (7)で表 される.

$$
\gamma=\left(1-\frac{\Delta T_{2}}{T_{0 e x, C}}\right)\left(1+\frac{\Delta P_{2}}{P_{0 i n, N}}\right)^{\frac{\kappa-1}{x}}
$$

タービン始動圧及ひ注宿機则出からタービン排気まで の圧力損失の和が，圧縮機のサ一沙圧を越えるとタービ ンシステムとして成立しない：よって実祭のタービンシ ステムで次式に示寸条件の成立が必要になる。

$$
\sigma \geq \pi+\theta_{2}
$$

4-2 流れ解析手法 タービン始動点近傍での 翼車内の流れ状態を把握するため3 次元粘性流体解 析を行った. 解析手法はDawes Code ${ }^{(11)}$ を用いた定 常流解析である. 乱流モデルは標準形 $\kappa$ - $\varepsilon$ モデル (12) $^{(2)}$ を使用している.

解析領域は図 4 に示すようにタービンノズルと翼 車のそれぞれに対して翼形を含む 1 ピッチ分を扱う。 入口境界は, ノズル入口半径の 1.1 倍に, また, 夕 一ビン翼車出口境界は, 翼出口での翼 1 ピッチ分の 長さを翼出口端から軸方向に延長した位置に設定し た. 境界条件は入口全圧, 全温とタービン翼車の出 口静圧を与えた。

メッシュ分割数は翼高さ方向 $22 \times$ 周方向 $22 \times$ 流 れ方向 90 分割である.

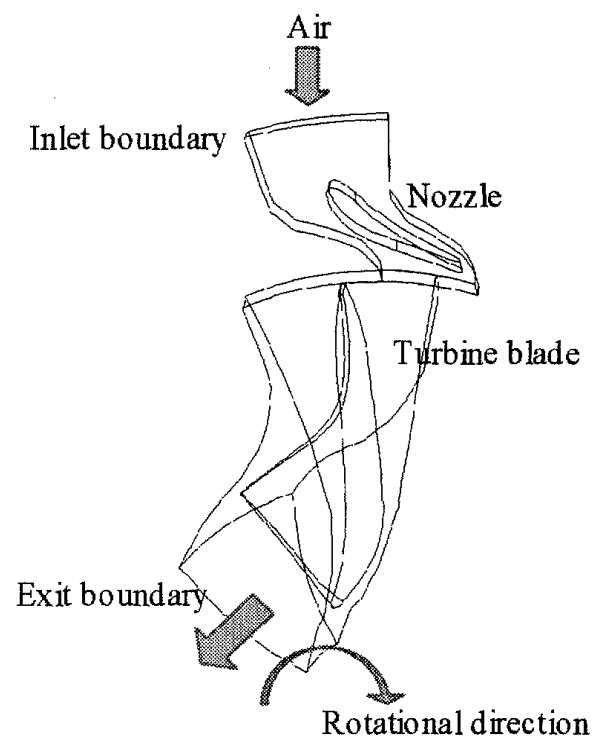

Fig. 4 Calculation region

\section{5. 試験装置及乙弪験方法}

\section{5-1 圧縮機 - タービン分離試験 分離試験は} 圧縮機の吐出と，タービンの流入空気ラインを分離 して，それぞれを独立した状態で作動させる. 压縮 機吐出部で再生熱交換器との接続管を外し, 圧縮機 吐出空気はそのまま大気に放出し，タービンへの流 入空気は別置の空気源から流量調節弁を介して燃焼 器の入口側に供給した. タービンの流入条件は圧縮 機の吐出条件に関係なく, 流入圧力を大気圧から絶 対圧 $0.5 \mathrm{MPa}$ まで, 流入温度を常温〜 $523 \mathrm{~K}$ までの範 囲で設定することができる.

試験方法は，初めに発電機ロー夕を起動させ試験 回転数まで昇速して回転数を保持する.この状態で, 別置空気源からタービン側に空気を供給する，空気 
流量の測定は，別置空気源と燃焼器入口間に設けた 長さ $5 \mathrm{~m}$ ，直径 $0.15 \mathrm{~m}$ の直管部に設置したオリフィ スで計測した. また, 空気温度と圧力はタービン， ズル上流に設けたセンサーで計測した. 温度は $\mathrm{K}$ 型 熱電対で，圧力は半導体型圧力センサー(横河 $\mathrm{M} \& \mathrm{C}$ 製FP201 )を用いた. また，タービン反動度の計測の ためタービンノズル出口とタービン翼車入口間に静 圧孔を設け，上記と同様の半導体型圧力センサーで ノズル出口静圧を測定した. 反動度は断熱熱落差の 定義式において空気を理想気体と仮定してエンタル ピーを圧力比によって書き換えた式 (9)によって算 出した。

$$
R=\frac{\left(\frac{P_{e x, N}}{P_{0 i n, N}}\right)^{\frac{\kappa-1}{\kappa}}-\left(\frac{P_{0 e x, T}}{P_{0 i n, N}}\right)^{\frac{\kappa-1}{\kappa}}}{1-\left(\frac{P_{0 e x, T}}{P_{0 i n, N}}\right)^{\frac{\kappa-1}{\kappa}}}
$$

なお，タービンへの空気流量の過剩供給を避ける ため, タービンノズル入口圧力を，その回転数での 圧縮機サージ压の 1.01 倍までとした.

5・2 プロト機試験 プロト機訊験は圧絔機吐 出部の配管を再生熱交換器に接続してマイクロガス タービン装置として復旧した状態で寒施した. 着火 の有無によるタービン流量の変化を測定した. プロ 卜機試験での流量測定は，吸気ダクトに設置したフ イルタ差圧を用いて算出した. フィルタは予め校正 風洞において差圧と流量の関係が把握されている.

\section{6. 計算結果及乙試䤅結果}

6-1 半径流タービンの始動圧力比 本研究で 開発しているプロト機に用いている圧縮機とタービ ン翼車の形状及び圧縮機性能を基に，本プロト機で のタービン始動圧力比を算出する. 図 5 に本研究で 用いた圧縮機の特性曲線( ${ }^{(9)}$ と，そのサージラインを 示す.サージラインの設定方法は文献(13)を用いた。 計算には圧縮機及びタービン翼車形状の数值として 表 1 に示す值を用いた。 ここで，タービン翼車の代 表出口径は，タービン出口での翼のチップ半径と八 ブ面半径の相乗平均值とした. また, 計算では, 夕 一ビン翼車の内外径比は表 1 に示寸数值で固定し, 翼車外径比 $\alpha$ をパラメータとしてタービン始動圧力 比の変化を調べた.
はじめに, $C_{\eta}=1$ と仮定した場合のタービン始動 圧力比として式 (3)及び式 (5)の計算結果を図 6(a) に示寸． 圧縮機入口空気温度が $288 \mathrm{~K}$ の場合, ター ビンと圧縮機の翼車外径比 $\alpha$ が 1.2 以上で, タービ ン始動圧がサージ圧よりも高くなるためタービンは 始動できない， $\alpha$ が1.1 以下では，起動から定格回 転数 $(51,000 \mathrm{rpm})$ まで, どの回転数に対しても, 夕 ービン始動圧はサージ圧以下になるため始動できる. また，タービン入口空気温度を $523 \mathrm{~K}$ に上げた場合 は， $a=1.3$ の定格回転数近傍を除き，いずれも夕 ービン始動圧はサージ圧以下になっている.つまり， 着火によってタービンの動作は圧縮機サージ圧から の裕度を大きく取れることを表している.

Table 1 Dimensions for turbine and compressor

\begin{tabular}{|l|c|c|}
\hline \multicolumn{1}{|c|}{ Item } & Symbol & Radius $(\mathrm{m})$ \\
\hline Turbine inlet & $\mathrm{r}_{\mathrm{in}, \mathrm{T}}$ & 0.113 \\
\hline Turbine exit & $\mathrm{r}_{\mathrm{ex}, \mathrm{T}}$ & 0.042 \\
\hline Compressor exit & $\mathrm{r}_{\mathrm{ex}, \mathrm{C}}$ & 0.097 \\
\hline
\end{tabular}

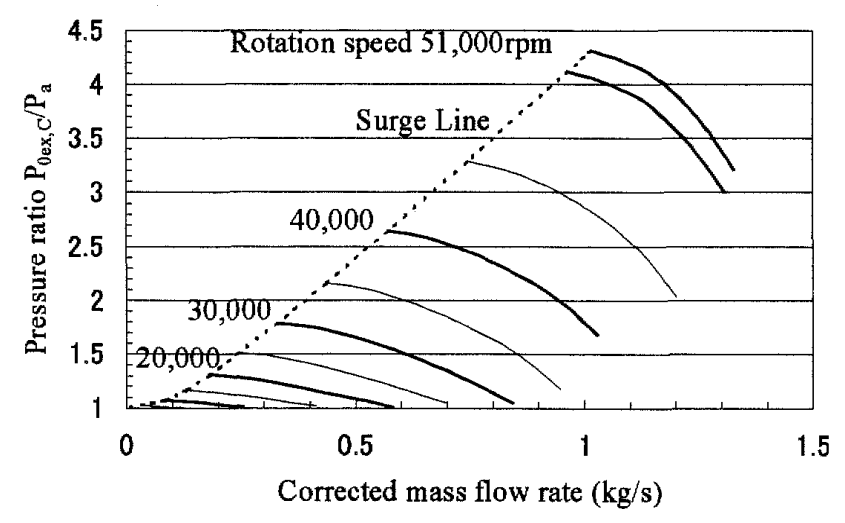

Fig.5 Compressor performance characteristics

図 6 (b)は，後述する実験値との比較加 $C_{\eta}=0.85$ とした場合の結果である. 圧縮機入口空気温度が $288 \mathrm{~K}$ の場合, タービンと圧縮機の翼車外径比 $\alpha=1.3$ で，タービン始動圧がサージ圧よりも高くなるため タービンは始動できなくなる. タービン入口空気温 度を $523 \mathrm{~K}$ に上げた場合は， $\alpha=1.3$ まで回転開始か ら定格回転数までの全域でタービン始動が可能なこ とが分かる：これらの結果は，圧縮機吐出からター ビン排気までの圧力損失と, 圧縮機吐出からタービ ンノズル入口までの温度降下を無視した条件であり， このような理想的な状態においても，タービンの自 立運転可能な範囲は， $\alpha=1.3$ を超えることは無い． なお，以後の計算において， $C_{\eta}$ は全て 0.85 とする. 
次にタービン始動圧比に及ぼすタービン入口空気 温度の影響について述べる. 式 (3)からタービン入 口空気温度が上昇すればタービン始動圧は低下する ことが分かる. 図 7 には回転数 $5,000 \mathrm{rpm}$ と 10,000 $\mathrm{rpm}$ のタービン始動圧を各 $\alpha$ に対してタービン入口 空気温度を変化させた場合の式 (3)の計算結果を示 す．空気温度を $500 \mathrm{~K}$ 程度まで上げることで，常温

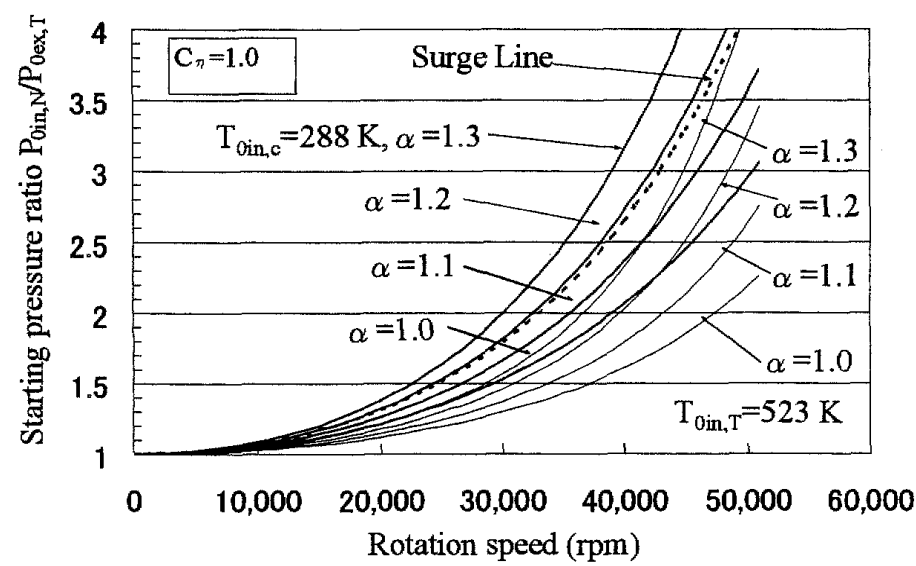

Fig. 6 (a) Calculation results of starting pressure ratio

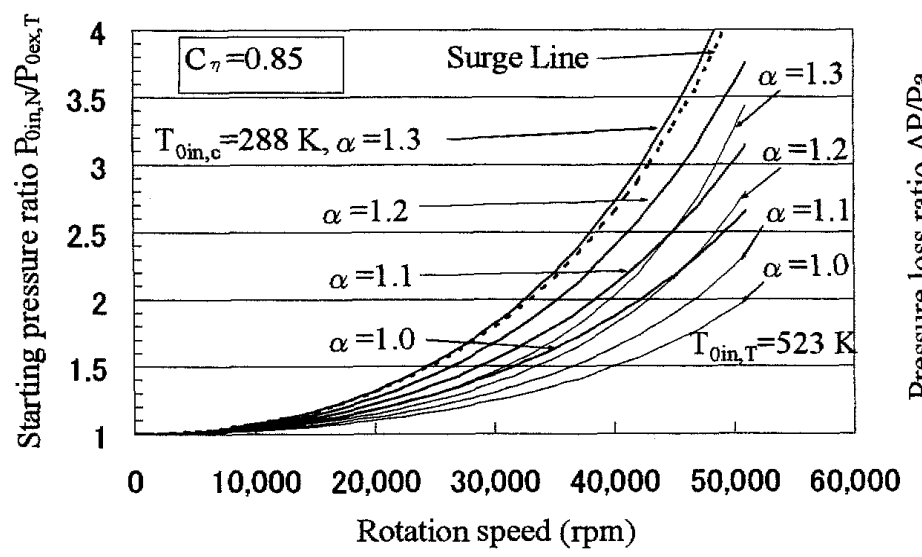

Fig. 6 (b) Calculation results of starting pressure ratio

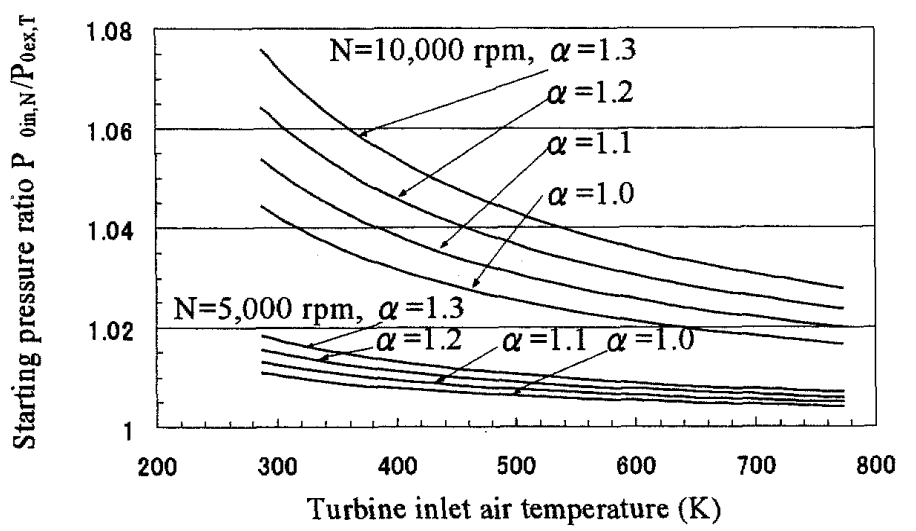

Fig. 7 Temperature effect of starting pressure ratio
に比べて，タービン始動圧を大幅に低減できる.し かし, $500 \mathrm{~K}$ 以上の温度領域に対しては, 温度上昇に よる始動圧比の低减効果㲺さくなっている.

次に圧縮機吐出加らタービン排気までの圧力損失 及び圧縮機吐出からタービンノズル入口までの温度 降下の影響について述べる. 式 (6)に使用する $\theta_{1}$ 及 びノはプロト機試験の結果から得られた值を使用し た. 図8にその結果を示す. 再生熱交換器の圧力損 失は，図8に示す測定值を回転数の 2 次式で近似し て与えた。図 9 に計算結果を示す。図 9 は圧縮機の サージ圧力からタービン始動圧力と圧力損失を差し 引いた值をサージ圧力で除した值で, タービン始動 に対する裕度を示している，つまり，この值が正で タービンが始動することになる，逆に負の場合は， タービン始動に必要な圧力がサージ圧を越えるため, タービン翼車はタービンとして作動できないことを 意味する. 図 9 で, 計算条件の $y=1$ は温度降下を無 視した結果であり， $\gamma \neq 1$ は, 図8に示した $\gamma$ を与 えた結果である.

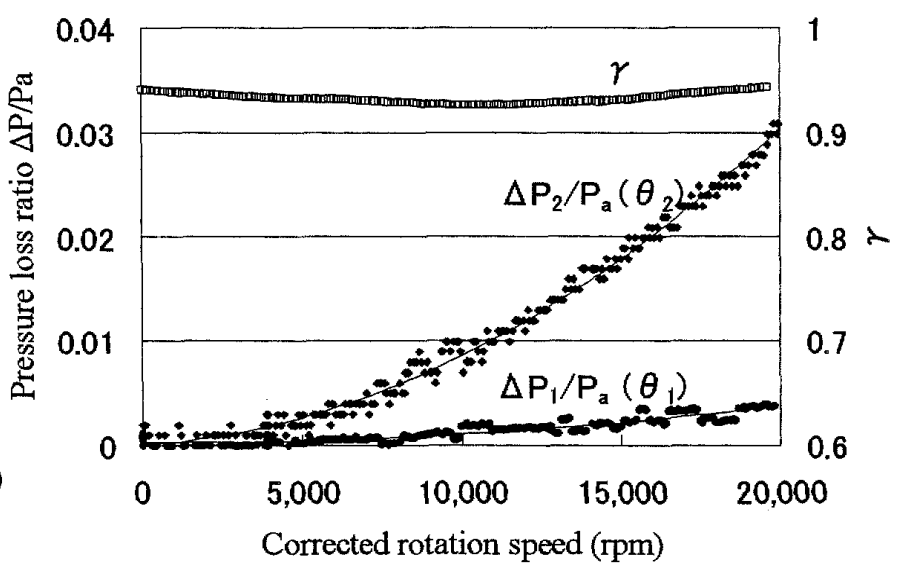

Fig. 8 Calculation conditions for $\gamma$ and $\theta$

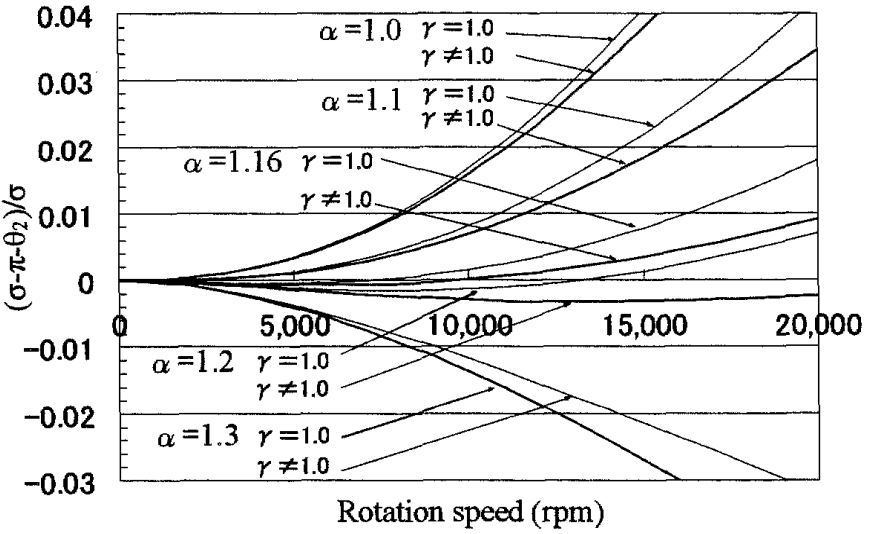

Fig. 9 Margins for starting pressure 
$a=1.1$ 以下では温度降下の有無に関わらず裕度は 回転開始から正になっており，回転数の増加に伴い 増加し, タービン始動に関してはまったく問題が無 いことが分かる. 一方， $\alpha=1.3$ は回転開始からター ビン始動圧の裕度は負になっており，本プロト機で は, 圧縮機外径の 1.3 倍以上の大きさを有するター ビンは始動できないことを示している. $\alpha=1.2$ の結 果は， $\gamma=1$ ，つまり温度降下を無視した場合には, 回転開始汃ら裕度は零近傍にあり，13,000 rpm 以上 で正になる.しかし，温度降下を考慮した結果では， 裕度は回転開始とともに負になり，20,000 rm にお いても明確に負の領域に留まったままである.

タービンと圧縮機の翼車外径比 $\alpha=1.16$ は本プロ 卜機で採用したタービンと圧縮機の翼車外径比であ る．温度降下を考慮した結果でも，裕度は回転数の 増加に伴い正側に移行している。 $\alpha=1.16$ は, 本プ ロト機でタービンを始動させるための限界值に近い ものと考えられる.

図 9 から，タービン始動に関しては，圧縮機吐出 からタービンノズル入口までの温度降下の影響が大 きいことが分かる.

6-2 圧縇機・タービン分離試験結果 図 10 はタービン回転数を $5,000 \mathrm{~mm}$ 及び $10,000 \mathrm{rpm}$ に保 持した状態でタービンに空気を供給した時のタービ ンノズル入口全圧と大気圧の比を示した図である.

計測結果から 5,000 $\mathrm{mpm}$ 及び $10,000 \mathrm{rpm}$ ともター ビン入口空気温度が $297 \mathrm{~K}$ の方が $523 \mathrm{~K}$ の場合より も, 圧力比嵪くなり，タービンノズル入口空気温 度によって有意差を生じることが分かる.タービン 入口空気温度を高温にすることで，同じ流量を流す 場合には圧力が低くなり，また，入口圧力が同じ場 合には，温度を高めることで流量が増加する．図 10 で，それぞれの試験ケースにおいて流量零の点がタ ービン始動点である. 図の縦軸流量零の線上に式 (3)から求まるタービン始動圧力比で, $C_{n}=0.85$ の場 合の結果を示した. 各計算結果は, 計測点の圧力比 を流量に対して 2 次式で近似した場合 (図中の細線) の外挿点とほぼ一致する。 つまり, 式 (3), 式 (5), 及び式 (6)でタービン翼車の圧縮作用の効率 $\eta_{T}$ と タービン作用の効率 $n_{C}$ の比 $C_{\eta}$ を 0.85 とすることで, それらの式はタービン始動圧力を予測する式として 適用できることが分かる．翼車は元来タービン効率 が高くなるように設計されているため，始動する間 際の少流量域の流動状態であっても，膨張流が発生 するときの効率の方が遠心力により昇圧動作を発生 するときの効率よりも高くなっているものと考えら

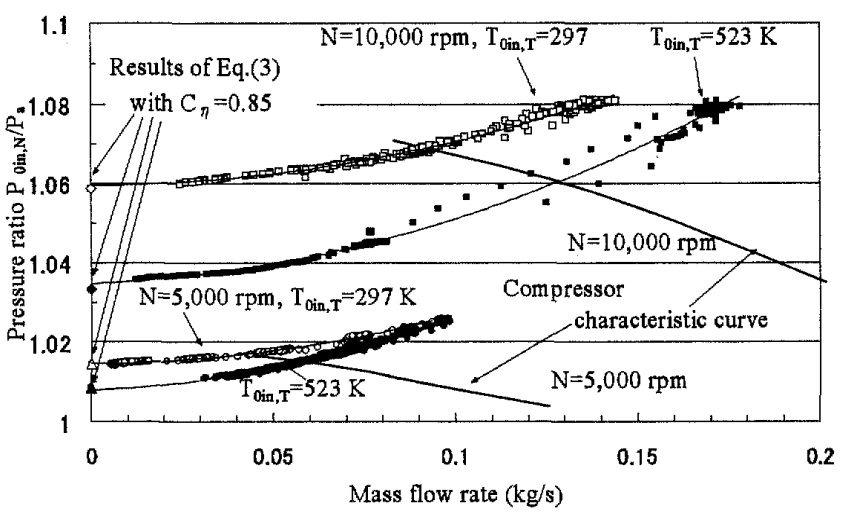

Fig. 10 Experimental results for pressure ratio

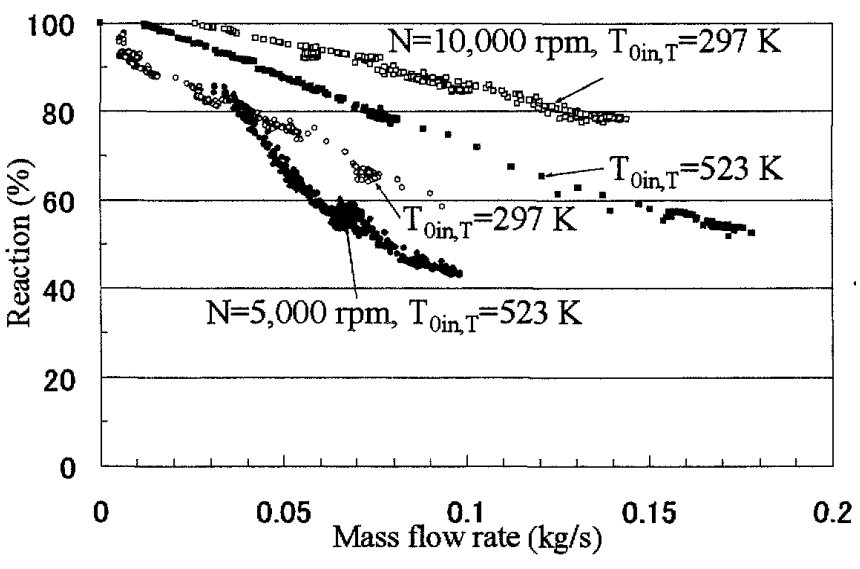

Fig. 11 Experimental results of the reaction

れる. つまり， $\eta_{T}>n_{C}$ のため $C_{\eta}$ は 1 以下の值で 実験值と良好に一致したものと思われる.

図 10 にはそれぞれの回転数での圧縮機の特性曲 線もプロットした. $5,000 \mathrm{~mm}$ と $10,000 \mathrm{~mm}$ とも, 空 気温度 $297 \mathrm{~K}$ ではタービンの流量線と圧縮機の特性 曲線は，圧縮機のサージ点に近いところでマッチン グしている. 空気温度を上げることでマッチング点 は大流量側に移行するため，着火によって圧縮機と タービンのマッチング点を，圧縮機の安定な運転範 囲に移動できる.

図 11 はタービンノズル出口静圧の計測から式 (9) で算出した反動度をプロットしたものである．回転 数 $5,000 \mathrm{pm}$ と $10,000 \mathrm{mpm}$ で入口空気温度を高くす ると反動度が低下しており，タービンノズルで流れ が加速されていることが分かる.タービンノズル入 口空気温度の差異による流動状態への影響に関して は次節の流れ解析結果と併せて考察する.

6-3 タービン翼間流れ解析結果 対象とする 流れ場は低回転数領域であり定格流量に比へて極め て流量が少ない. $5,000 \mathrm{pm}$ では定格流量の約 $5 \%$, 
10,000 rpm でも $15 \%$ 程度であり, 解析精度の面から 定量的な考察を行うことは困難と思われるため, こ こではタービン入口条件の差異による流動状態の変 化のみを調べる. 計算は分離試験の $10,000 \mathrm{rpm}$ を対 象とした．計算条件を表 2 に示す。

図 12 にケース 1 の結果を，また図 13 にケース 2 の結果を示す. 図は相対流れの流線を示したもので, 色は相対速度の大きさを示している. タービン翼車 部を中心にノズル出口部を含めて示し, 翼車のハブ 面とタービンチップ面，及びその中間面での結果を 示した. 両ケースで明確に異なる点は，タービン， ズル出口の流速と，タービン翼車入口部の流れ状態 である. 入口空気温度 $297 \mathrm{~K}$ の場合に比べて, $523 \mathrm{~K}$ の方が，タービンノズルでの加速が大きく，ノズル 出口部での速度で, $297 \mathrm{~K}$ の場合が約 $30 \mathrm{~m} / \mathrm{s}$ に対し て, $523 \mathrm{~K}$ の場合は約 $90 \mathrm{~m} / \mathrm{s}$ と $297 \mathrm{~K}$ の結果に比心 て3 倍程度に増速してタービン翼車に流入している. 両ケースで圧力比注同一であるが，温度が異なるた め, タービンの熱落差としては, 温度上昇分による エンタルピーの増加は約 1.8 倍になる. このためノ ズルで流れが膨張し易くなる.これは分離試験で反 動度がタービンノズル入口空気温度を上げると低下 したことと一致する. また, 入口空気温度 $297 \mathrm{~K} の$ 結果では, タービン翼車入口部で，回転方向と逆向 きの大きな渦がハブ面からチッップ面の翼間流路方向 のほぼ全域に渡って発生している.この渦がノズル からタービン翼車への流れを塞いでいる. チップ面 側の翼負圧面近傍で, 僅かにノズルからの流れが夕 ービン翼車に流入していることが分かる。

一方, 入口空気温度 $523 \mathrm{~K}$ の結果は図 12 で見られ るタービン入口部での大規模な渦の発生は無い.入 口空気温度の上昇によるノズル出口流速の増加は, タービン翼車の回転によってタービン翼車入口部の 翼間に発生する大規模な渦の発生を弱め, 翼間通過 流量を増加させていることが分かる。なお，本計算 結果の流量は，ケース 1 で $0.135 \mathrm{~kg} / \mathrm{s}$ ，ケース 2 で $0.172 \mathrm{~kg} / \mathrm{s}$ と実験結果に近い值が得られている.

6.4 プロト機訆験結果 プロト機試験では, 着火回転数を $4,000 \mathrm{rpm}$ とした.これは発電機ロー 夕の低次固有振動数が $5,000 \mathrm{rpm}$ 以上に存在するた め，危険速度をスムーズに通過するためにも，着火 を早めて圧縮機の安定運転範囲に入れるためである. プロト機試験では, 着火によるタービンノズル入口 空気温度の変化による流量変化を調べた. 着火時の 目標燃焼温度は $523 \mathrm{~K}$ と $773 \mathrm{~K}$ の 2 種類とした. 図 14 に横軸老修正回転数として, 着火直前の空気流量
Table 2 Boundary conditions for numerical calculations

\begin{tabular}{|c|c|c|c|}
\hline \multirow{2}{*}{} & \multicolumn{2}{|c|}{ Inlet boundary } & Exit boundary \\
\cline { 2 - 4 } & $\mathrm{P}_{0}(\mathrm{kPa})$ & $\mathrm{T}_{0}(\mathrm{~K})$ & $\mathrm{P}(\mathrm{kPa})$ \\
\hline Case 1 & 108 & 297 & 100 \\
\hline Case 2 & 108 & 523 & 100 \\
\hline
\end{tabular}

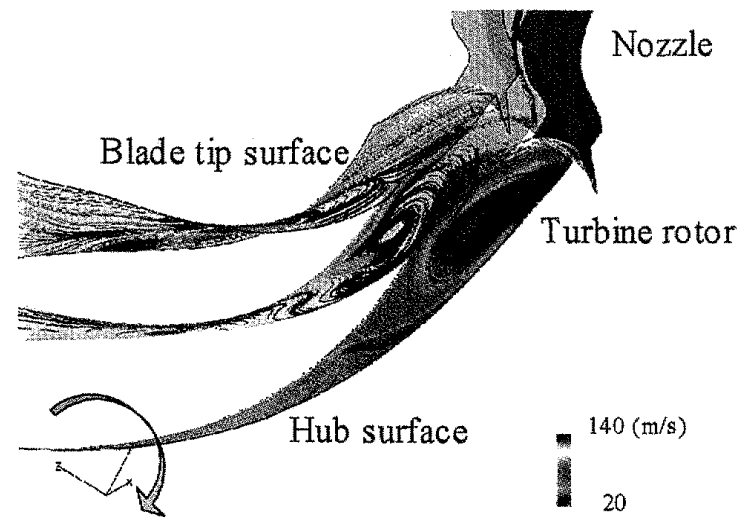

Rotational direction

Fig. 12 Calculation results of Case 1

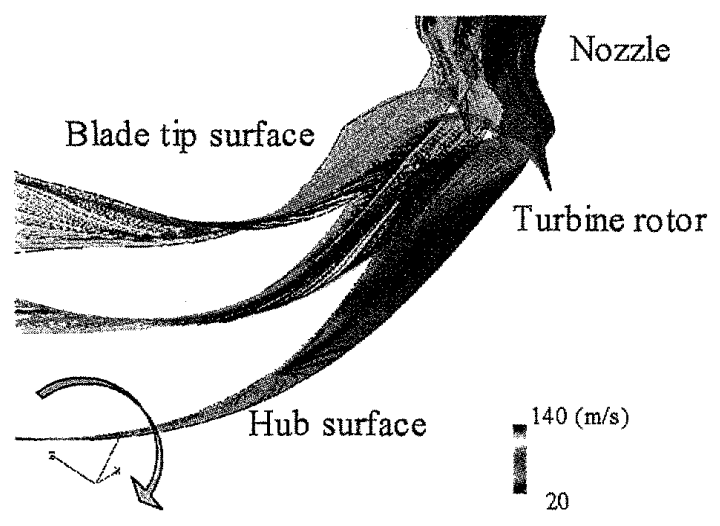

Rotational direction

Fig. 13 Calculation results of Case 2

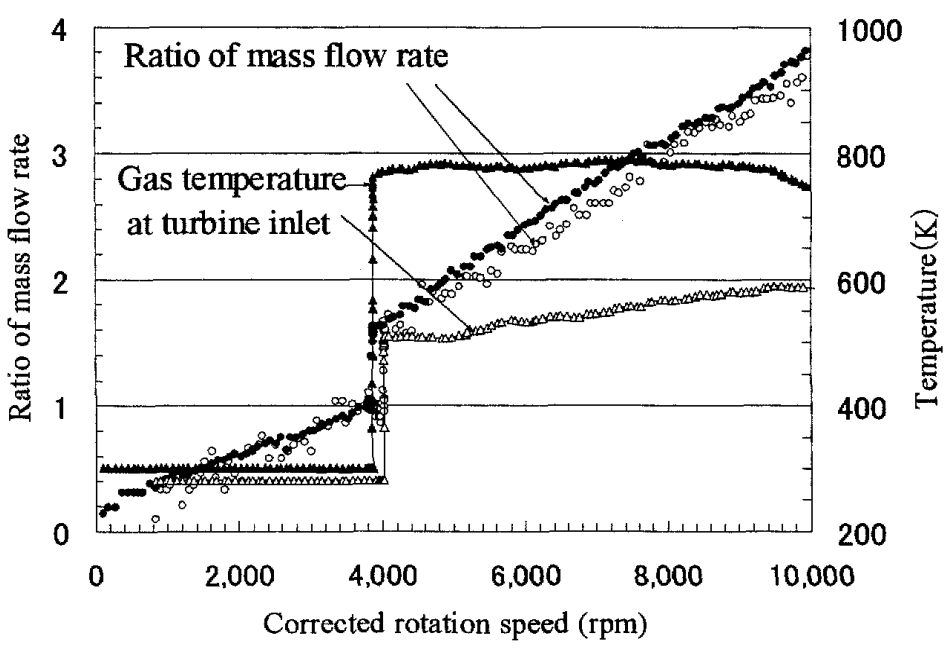

Fig. 14 Experimental results of the prototype machine 
との流量比とタービンノズル入口ガス温度の変化を 示した. 図 14 において, 着火前のタービンノズル入 ロガスは空気を意味し，着火後は燃焼ガスを意味す る. 両ケースとも着火によって空気流量が着火直前 に比べて約 1.5 倍に増加している. 図 10 の分離試験 結果では回転数 $5,000 \mathrm{~mm}$ での結果であるが，ター ビンと圧縮機のマッチング点での流量は，タービン 入口空気温度が $297 \mathrm{~K}$ から $523 \mathrm{~K}$ に上昇することで 図 14 の結果と同様に約 1.5 倍に増加しており，プロ 卜機試験は分離試験と同等な傾向を示した．燃焼温 度を $773 \mathrm{~K}$ にしたケースでは，燃焼温度 $523 \mathrm{~K}$ の 結果と比べて流量増加率の変化に大きな差異は見ら れなかった. 図 7 に示した計算結果から，常温から $500 \mathrm{~K}$ の範囲に関してはタービンノズル入口空気温 度の影響が著しく現れるが，それ以上の温度領域に 関しては，空気温度の上昇に対する始動圧力の低减 効果は減少していた. プロト機試験の結果からも燃 焼温度 $523 \mathrm{~K}$ 上 $773 \mathrm{~K}$ で着火後の流量変化に有意な 差は生じていない.

本プロト機のように，低速回転数での着火が可能 になると，与えられた圧縮機に対して，タービン翼 車径をタービン自立運転可能な限界まで大きくでき るため, タービン出力の増加及び発電効率の向上に 寄与することできる．なお，本プロ卜機の発電試験 では，送電端発電効率はマイクロガスタービンとし ては高効率の領域である $33.2 \%{ }^{(9)}$ を記録している。

\section{7. 結 論}

本研究では, 半径流タービンの適正寸法に関して, 特にタービンの起動が安定に行えるようなタービン と圧縮機の翼車外径比の関係に関して，理論的な考 察と，その検証試験としてプロト機での確認試験を 実施して以下の結論を得た。

（1）半径流タービンの始動圧力に関して，ター ビンの内外径比，タービンと圧縮機の翼車外径比， 回転数及び圧縮機入口空気温度またはタービンノズ ル入口空気温度から，そのタービンを始動させるの に必要な圧力比を与える基礎式を導出した。

（2）上記のタービン始動圧力を与える式は，タ ービン翼車の圧縮作用時の効率とタービン作用時の 効率の比 $C_{\eta}=0.85$ の場合において，タービン始動圧 は分離試験結果の外挿值之良好に一致した。

（3） 圧縮機のサージを回避してタービンを始動 できるタービンと圧縮機の外径比には限界值が存在
し，本プロト機では再生熱交換器の圧損を無視した 場合でも 1.3 を超えることはできない.

（4）圧縮機吐出からタービン排気までの圧力損 失上, 圧縮機吐出からタービンノズル入口までの温 度降下を考慮すると，タービン始動圧力はこれらを 考慮しない場合に比へ増加し，特に，圧縮機吐出か らタービンノズル入口まで温度降下の影響が大きい。 圧力損失と温度降下を考慮した場合，本プロ卜機に おいて, タービンと圧縮機の外径比 1.16 は, 圧縮機 のサージを回避してタービンを始動できる理論限界 に近い值と考えられる.

（5）タービンノズル入口空気温度の上昇は，タ ービンノズルでの流れを増速させ，タービン翼車入 口部に形成される大規模な渦の発生を弱め，翼車通 過流量を増加させる.

（6）理論限界に近いタービンと圧縮機の翼車外 径比を維持してタービン起動を安定させる方法とし て，低速回転数で着火する運転方法を提案し，プロ 卜機試験で安定に起動できることを確認した。

\section{謝 辞}

本研究は，新エネルギー・産業技術総合開発機構 （NEDO）の委託による「次世代マイクロタービン トライジェネレーションの研究開発」の一部である.

ここに記して謝意を表します。

\section{文献}

(1) Craig, P., The Capstone Turbogenerator as an Alternative Power Source, SAE Technical paper series 970292, (1997-2).

(2) O'Brien, P., Development of a $50 \mathrm{~kW}$ Low-Emission Turbogenerator for Hybrid Vehicles, ASME 98 GT 400, (1998-6).

(3) Rodgers, C., $25-5$ kWe MICROTURBINE DESIGN ASPECTS, ASME 2000-GT-0626, (2000).

(4) Ishii, K., Micro Gas Turbine System (in Japanese), (2002), p59, Ohm publishing.

(5) Tsuchiya, T. and Okamoto, M., Evaluations on the Economical Competitiveness of Micro Gas Turbine Cogeneration Systems based on Efficiency and Maintenance Cost, Proceedings of the Asian Congress on Gas Turbines, ACGT 2005-067, (2005).

(6) Watanabe, I., Katagiri, R, Konishi, K. Tashiro, S., and Yoshiki, $H$., Effects of windage characteristics for predictions of turbo-charger turbine performance (in Japanese), Proceeding of $28^{\text {th }}$ annual gas turbine conference, (2000-6), pp.53-58.

(7) Tatsumi, T., 32-PS Small Gas Turbines (in Japanese), Journal of internal combusion engine, Vol.24, No.308, (1985), pp.68-70. 
(8) Karen, A, T., Advanced energy system program annual report, Gas Research Institute No.89-62095, (1989-2).

(9) Nakano, S., Kishibe, T., Araki, H., Yagi, M. Tsubouchi, K., Ichinose, M, Hayasaka, Y., Sasaki, $\mathrm{M}$, Inoue, $\mathrm{T}$, Yamaguchi, $\mathrm{K}$, and Shiraiwa, $\mathrm{H}$, Development of a $150 \mathrm{~kW}$ microturbine system which applies the humid air turbine cycle, $A S M E$, GT2007-28192, (2007).

(10) Nakano, S., Kishibe, T., Inoue,T., and Shiraiwa,H., AN Advanced Microturbine System with Water Lubricated Bearings, $12^{\text {th }}$ Int. Symp. Transport Phenomena and Dynamics of Rotating Machinery, ISROMAC12-2008-20185, (2008-2).
(11) Dawes, N. W., Development of a 3D Navier Stokes Solver for Application to All Types of Turbomachinery, ASME Paper No.88-GT-70, (1988).

(12) Launder, B. E. and Spolding D. B., The Numerical Computation of Turbulent Flows, Comput. Method in Applied Mech. And Eng., vol.3 (1974), pp. 269-289.

(13) Mishina, $H$, and Nishida, H., Performance prediction of centrifugal compressor, First report, Prediction method and calculation results (in Japanese), Transactions of the Japan Society of Mechanical Engineers, Series B, Vol. 49, No.441, (1983), pp.1000-1009. 